\title{
Effects of Different Mixing Schedules on Phytoplankton, Zooplankton and Nutrients in Marine Microcosms
}

\author{
Candace A. Oviatt \\ Graduate School of Oceanography, University of Rhode Island, Kingston, R.I. 02881, USA
}

\begin{abstract}
An experiment was carried out with different mixing schedules in marine microcosms. Continuous mixing resulted in higher chlorophyll concentrations, lower nutrient concentrations and lower zooplankton biomass than no mixing. No mixing caused water-column stratifications of chlorophyll and nutrients, as well as of organisms such as flagellates and rotifers adapted to low-mixing regimes. The most dramatic result was the low biomass of zooplankton in the continuously mixed microcosms and the high biomass of zooplankton in the unmixed microcosm.
\end{abstract}

\section{INTRODUCTION}

Physical understanding of turbulence in estuaries is still in a primitive state, in part because it is a highly variable phenomenon, and in part because reliable methods and instrumentation for measuring turbulence do not yet exist. Without physical understanding of the processes involved, ecological comprehension becomes most difficult. Yet we have assumed from the beginning of the development of marine microcosm research that turbulence was an important physical process which should be scaled appropriately (Oviatt et al., 1977; Perez et al., 1977; Nixon et al., 1979, 1980). Other microcosm facilities, notably CEPEX, which did not initially take turbulence into account had the phytoplankton dominated by dinoflagellates and microflagellates rather than the more appropriate diatoms (Thomas and Seibert, 1977). A later experiment indicated that mixing, nutrients and light regimes controlled the dominance of diatoms or flagellates (Parsons et al., 1978). In small microcosms (1501) varying effects on phytoplankton and zooplankton were recorded under different mixing regimes (Perez et al., 1977; Nixon et al., 1979). The present paper deals with effects of different mixing schedules in large microcosms $(13,0001)$.

In the Marine Ecosystems Research Laboratory (MERL), the design criteria for mixing microcosms require that the water column be well mixed and the mixer be capable of resuspending sediment from the bottom of the tank in order to produce levels of suspended material in the water column similar to those in Narragansett Bay. During 1978, the annual time weighted mean for suspended load was $3.2 \mathrm{mg} \mathrm{l}^{-1}$ in the control microcosms and $5.1 \mathrm{mg} \mathrm{l}^{-1}$ in the lower west passage of Narragansett Bay. Other measurements of mixing in the tanks also indicate that the present mixer is satisfactory, but they also have shown that horizontal advection and gas diffusion at the water surface were less and that vertical advection was greater than in the bay (Nixon et al., 1980). Despite such differences, biological and chemical cycles in the tanks appear to be similar to the bay (Pilson et al., 1979,1980 ). Except for a brief storm simulation (Oviatt et at., submitted), the effects of the full range of the present mixing schedule capabilities have never been examined over a longer period of time.

Mixing energy is imparted to the tanks by the movement of a plunger (diameter $50 \mathrm{~cm}$ ) located $1 \mathrm{~m}$ above the center of the sediment surface (Fig. 1). A polyvinyl chloride shaft connects the plunger to the crank of an electric mixing motor. During normal operation, the shaft moves in an elliptical orbit (vertical dimension $60 \mathrm{~cm}$ ) at $5 \mathrm{rpm}$. The tanks have been mixed on a normal schedule of $2 \mathrm{~h}$ on and $4 \mathrm{~h}$ off to simulate tidal currents. However, schedule and speed of mixing are flexible and can be changed to any schedule and any speed up to $14 \mathrm{rpm}$.

From December 12, 1978 to April 27, 1979 a mixing experiment was carried out in three of the MERL 


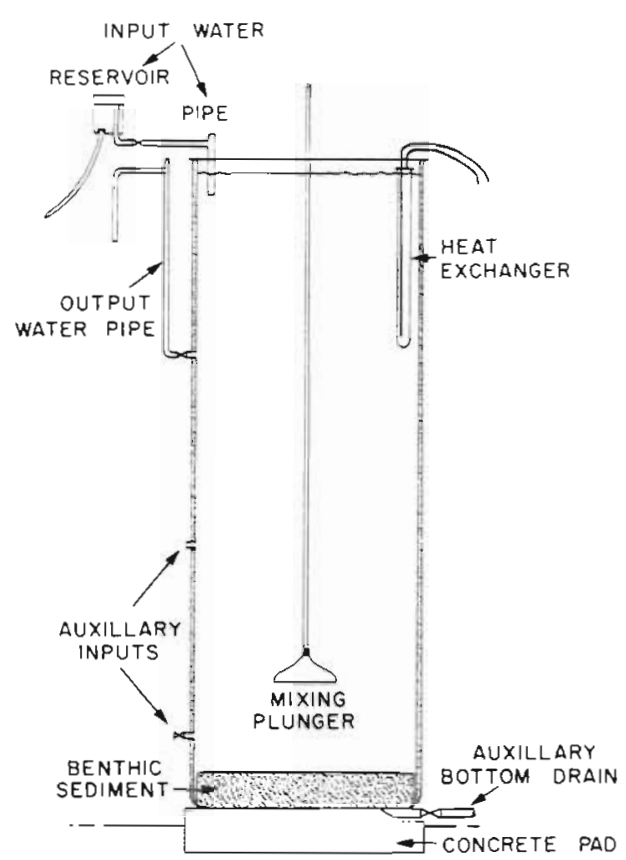

Fig. 1 Cut-away view of MERL microcosm. Tank diameter: $1.83 \mathrm{~m}_{i}$ tank height: $5.49 \mathrm{~m}$; water surface area: $2.63 \mathrm{~m}^{2}$; depth of water: $5.00 \mathrm{~m}$; volume of water: $13.1 \mathrm{~m}^{3}$; area of sediment: $2.52 \mathrm{~m}^{2}$; depth of sediment: $0.30 \mathrm{~m}$

microcosms. Tanks 6 and 8 were mixed continuously at 5 rpm. The mixer was removed from Tank 3 and the only mixing that this tank received was from sampling or cleaning operations. The other tanks, Control tanks 1,5 , and 4 and Oil-recovery tanks 2, 7, and 9, were mixed on the normal schedule ( $2 \mathrm{~h}$ on and $4 \mathrm{~h}$ off) at $5 \mathrm{rpm}$. The oil-recovery tanks had been subjected to an average concentration of $90 \mu \mathrm{g} \mathrm{l}^{-1}$ of number 2 fuel oil from March 6 to July 6, 1978. After July no oil was added to these tanks.

A heat exchange bottle broke in Tank 8 on February 12, 1979. Several liters of a calcium brine solution flowed into the tank. As a consequence, this tank was drained and refilled with fresh seawater. While the historical continuity of the water column was lost at this point, the experiment was continued. Apparently, there were no effects on the benthic community.

\section{METHODS}

\section{Total System Metabolism}

Oxygen concentration was measured early in the morning and late in the afternoon in each tank once a week to calculate diel apparent production and night respiration (Odum and Hoskins, 1958). Duplicate water samples were taken from each tank during mixing. In Tank 3 duplicate pooled samples were taken from three depths. Samples were fixed immediately and titrated within $24 \mathrm{~h}$ by Winkler titration (Strickland and Parsons, 1972). Oxygen diffusion measurements were made on the three different mixing regimes (Nixon et al., 1980) and diffusion corrections were made to all metabolism measurements. Production and respiration values over the period from December to May were graphed and integrated.

\section{Chlorophyll}

The fluorometric method of Holm-Hansen et al., (1965) was used to measure chlorophyll concentration. Filters were normally stored wrapped in aluminum foil over desiccant in a light-tight container at $-20^{\circ} \mathrm{C}$. Storage for longer than 2 weeks was avoided. Measurements were made with a Turner Model 111 fluorometer equipped with a high intensity lamp and a photomultiplier sensitive to red light.

\section{Production $\left({ }^{14} \mathrm{C}\right)$}

Pooled samples from each tank and a mid-depth sample $(\sim 2 \mathrm{~m})$ below the surface from Narragansett Bay at the MERL pump intake were used for the estimation of phytoplankton production. The method was basically that described by Strickland and Parsons (1972). Subsamples $(50 \mathrm{ml})$ of the well-mixed, pooled sample were placed into clear bottles equipped with ground glass stoppers and $1 \mu \mathrm{Ci}$ of ${ }^{14} \mathrm{C}$-labelled sodium bicarbonate was added to each. The tank samples were incubated at $0.1,0.5,1.0,2.5$, and $4.5 \mathrm{~m}$ for $24 \mathrm{~h}$ in their respective tanks. The bay sample was incubated in Tank 3 at the same depths and time as the tank samples. After incubation the bottles were filtered onto $25 \mathrm{~mm}$ glass fiber filters with low vacuum and the edges rinsed.

\section{Nutrient Chemistry}

Weekly pooled samples (equal volumes of water from $0.1,2.5$, and $4.5 \mathrm{~m}$ ) from each tank and the bay $(2.5 \mathrm{~m})$ were used for the determination of dissolved inorganic phosphate, ammonia, nitrate plus nitrite, and silicate. The samples were filtered into precleaned, deionized-water soaked plastic bottles using a $50 \mathrm{ml}$ plastic syringe equipped with a stainless steel or plastic filter holder. Millipore filters were used for the filtrations. If possible, samples were run the same day; if not, they were stored in a freezer at $-20^{\circ} \mathrm{C}$ after filtration.

A Technicon Autoanalyzer was used for the analyses. Four channels of chemical reactions were fabri- 
cated based on the procedures recommended by Friederick and Whitledge (1972). Each sample was run in triplicate, inter-spersed with a synthetic seawater wash. Standards were run before the samples each day; internal standards were added at least one every 40 samples.

\section{Benthic Respiration and Nutrient Regeneration}

An in situ plexiglass benthic chamber was designed and developed to fit over the sediment container in the bottom of the microcosms. The circular chamber was $1.76 \mathrm{~m}$ in diameter and $12 \mathrm{~cm}$ high. After incubation, PVC rods were dropped from the surface of the chamber to the surface of the sediment to obtain a measure of the water column. One-way valves in the surface of the chamber permitted water and organisms to pass through the chamber as it was lowered through the water column. To retrieve the chamber, rubber plugs were removed from the upper surface to reduce suction. Experiments carried out with dyes released in the chamber indicated no leakage from the chamber once it was in place.

Incubations for measurement of respiration and nutrient regeneration were carried out over $2-4 \mathrm{~h}$ periods with 1 to 3 tanks measured each day. Initial and final water samples were siphoned through a sampling hose for measurement of oxygen (Winkler titration: Strickland and Parsons, 1972) and ammonia. The tube was positioned half-way between the center and the edge of the chamber and directly opposite the inflow valve. Three Winkler bottles $(60 \mathrm{ml})$ were filled from the tube at each sampling ( 3 initials, 3 controls, 3 finals). The controls were incubated at the same depth and were used to correct for pelagic respiration. The ammonia samples were filtered with Reeve Angel $5.5 \mathrm{~cm}$ glass fiber filters, preserved (Degobbis, 1973), and analyzed (Solorzano, 1969). Oxygen and ammonia determinations were made the same day the samples were taken. The analytical precisions and the resulting effects on the fluxes for a 3 -h incubation were:

$$
\begin{gathered}
0_{2} \pm 0.025 \mathrm{mg} \mathrm{l}^{-1}= \pm 1.7 \mathrm{mg} \mathrm{m}^{-2} \mathrm{~h}^{-1} \\
\mathrm{NH}_{3} \pm 0.07 \mu \text { moles } \mathrm{l}^{-1}= \pm 4.7 \mu \text { moles } \mathrm{m}^{-2} \mathrm{~h}^{-1}
\end{gathered}
$$

\section{Zooplankton}

Weekly zooplankton counts were based on two pooled vertical tows per tank, from the bottom up, taken with the mixer in action. To reduce intertank variability caused by a tendency for some species to aggregate on the shaded side of the tank, one tow was taken on the light side and one on the shaded side. A
\# 20 plankton net with a diameter of $50 \mathrm{~cm}$ and a mesh size of $80 \mu \mathrm{m}$ was used for all samples. This technique was estimated to remove about $15 \%$ of the tank zooplankton population. The pooled sample was subdivided by a zooplankton splitter with $1 / 4$ of the sample being used for species identification and counts and $3 / 4$ for biomass. The fraction used for counts was preserved in buffered formalin and subsampled by stempel pipette until 300 animals (where possible) were identified and counted. Adult copepods, total copepodites, and nauplii were counted. The unpreserved biomass fraction was filtered through a \#10 plankton net and washed with deionized, distilled water to remove phytoplankton and salts, and frozen immediately. This procedure results in the loss of some nauplii from the biomass estimation, but is more accurate than including substantial errors due to phytoplankton biomass and salt weight. The resulting sample was freeze-dried in a Virtis automatic freeze dryer and then weighed on an analytical balance.

\section{RESULTS}

\section{Metabolism}

Apparent daytime productivity was lower over the 5 months in the unmixed tank (3) than in those continuously mixed ( 6 and 8 ), the apparent productivity in 3 being $64 \%$ and $58 \%$ of 6 and 8 , respectively (Table 1 ). Measures of productivity were also lower in the normally mixed tanks $(1,2,4,5,7$, and 9) than in the continuously mixed tanks, apparent productivity being $60 \%$ and $68 \%$, respectively. Apparent daytime productivity was lower in the control tanks $(1,4$, and 5) than in oil-recovery tanks $(2,7$, and 9). In our experiments this pattern has always been observed in oilaffected microcosms (Elmgren et al., 1980).

Phytoplankton blooms were often out of phase with each other in the individual microcosms resulting in considerable monthly variation within treatments. The winter-spring phytoplankton bloom occurred in Control tanks 1 and 5 in January, but did not peak until February in Tank 4 (Table 1). However, over periods longer than employed in this experiment variation is small within treatments and between control microcosms and bay. For example, 1976-77 annual productivity of the control microcosms and the lower bay were very similar, being 276 and $277 \mathrm{~g} \mathrm{C} \mathrm{m}^{-2} \mathrm{y}^{-1}$, respectively (Oviatt et al., 1981).

Nighttime respiration was highest in Tank 3 (unmixed) even though its apparent daytime productivity was lowest (Tables 1 and 2). In Tank 3 nighttime respiration was $108 \%$ of apparent daytime production. For all other mixing regimes this ratio ranged from 
Table 1. Apparent daytime monthly productivitiy $\left(\mathrm{g} \mathrm{O}_{2} \mathrm{~m}^{-2}\right.$ month $\left.{ }^{-1}\right)$ in the microcosms during mixing experiment. Where possible the coefficient of variation $(C . V=s / \bar{x}$ ) was calculated to show variations within treatment

\begin{tabular}{|c|c|c|c|c|c|c|c|c|c|}
\hline Treatment & Tank & December & January & February & March & April & Total & $\vec{x} \pm s$ & C.V. \\
\hline $\begin{array}{l}\text { Control, } \\
\text { normal mixing }\end{array}$ & $\begin{array}{l}1 \\
5 \\
4\end{array}$ & $\begin{array}{l}18 \\
23 \\
20\end{array}$ & $\begin{array}{l}47 \\
54 \\
33\end{array}$ & $\begin{array}{l}22 \\
18 \\
42\end{array}$ & $\begin{array}{l}35 \\
35 \\
29\end{array}$ & $\begin{array}{l}30 \\
37 \\
52\end{array}$ & $\begin{array}{l}153 \\
168 \\
175\end{array}$ & $165 \pm 11$ & $7 \%$ \\
\hline $\begin{array}{l}\text { Continuous } \\
\text { mixing }\end{array}$ & $\begin{array}{l}6 \\
8\end{array}$ & $\begin{array}{l}48 \\
18\end{array}$ & $\begin{array}{l}37 \\
39\end{array}$ & $\begin{array}{l}65 \\
67\end{array}$ & $\begin{array}{r}113 \\
33\end{array}$ & $\begin{array}{l}38 \\
86\end{array}$ & $\begin{array}{l}301 \\
243\end{array}$ & $272 \pm 41$ & $15 \%$ \\
\hline No mixing & 3 & 20 & 38 & 31 & 63 & 24 & 176 & 176 & \\
\hline $\begin{array}{l}\text { Oil recovery, } \\
\text { normal mixing }\end{array}$ & $\begin{array}{l}2 \\
7 \\
9\end{array}$ & $\begin{array}{l}46 \\
32 \\
35\end{array}$ & $\begin{array}{l}43 \\
41 \\
41\end{array}$ & $\begin{array}{l}26 \\
45 \\
44\end{array}$ & $\begin{array}{l}30 \\
45 \\
31\end{array}$ & $\begin{array}{l}34 \\
37 \\
41\end{array}$ & $\begin{array}{c}180 \\
50 \\
192\end{array}$ & $192 \pm 12$ & $7 \%$ \\
\hline
\end{tabular}

Table 2. Night respiration $\left(\mathrm{g} \mathrm{O}_{2} \mathrm{ml}^{-2}\right.$ month $\left.{ }^{-1}\right)$ in the microcosms during mixing experiment

\begin{tabular}{|c|c|c|c|c|c|c|c|c|c|}
\hline Treatment & Tank & December & January & February & March & April & Total & $\bar{x} \pm x$ & C.V. \\
\hline $\begin{array}{l}\text { Control, } \\
\text { normal mixing }\end{array}$ & $\begin{array}{l}1 \\
5 \\
4\end{array}$ & $\begin{array}{l}23 \\
22 \\
21\end{array}$ & $\begin{array}{l}38 \\
33 \\
23\end{array}$ & $\begin{array}{r}16 \\
5 \\
25\end{array}$ & $\begin{array}{l}10 \\
14 \\
11\end{array}$ & $\begin{array}{r}8 \\
14 \\
19\end{array}$ & $\begin{array}{r}93 \\
87 \\
100\end{array}$ & $94 \pm 6$ & $6 \%$ \\
\hline $\begin{array}{l}\text { Continuous } \\
\text { mixing }\end{array}$ & $\begin{array}{l}6 \\
8\end{array}$ & $\begin{array}{l}37 \\
17\end{array}$ & $\begin{array}{l}23 \\
32\end{array}$ & $\begin{array}{l}34 \\
39\end{array}$ & $\begin{array}{l}21 \\
10\end{array}$ & $\begin{array}{l}22 \\
28\end{array}$ & $\begin{array}{l}136 \\
125\end{array}$ & $131 \pm 8$ & $6 \%$ \\
\hline No mixing & 3 & 18 & 28 & 19 & 116 & 9 & 190 & 190 & \\
\hline $\begin{array}{l}\text { Oil recovery, } \\
\text { normal mixing }\end{array}$ & $\begin{array}{l}2 \\
7 \\
9\end{array}$ & $\begin{array}{l}36 \\
20 \\
31\end{array}$ & $\begin{array}{l}28 \\
26 \\
24\end{array}$ & $\begin{array}{l}18 \\
26 \\
25\end{array}$ & $\begin{array}{l}11 \\
16 \\
13\end{array}$ & $\begin{array}{l}11 \\
15 \\
11\end{array}$ & $\begin{array}{l}104 \\
103 \\
104\end{array}$ & $103 \pm 1$ & $1 \%$ \\
\hline
\end{tabular}

$48 \%$ to $57 \%$. However, this pattern was due to an anomalously high value in March (Table 2). Although there was no evidence in our records, the pooled oxygen samples may have been inappropriately taken. If the mean of February and April of $14 \mathrm{gO}_{2} \mathrm{~m}^{-2}$ month $^{-1}$ was used instead, the total would be $88 \mathrm{gO}_{2} \mathrm{~m}^{-2}$ in

Table 3. Benthic oxygen demand $\left(\mathrm{mg} 0_{2} \mathrm{~m}^{-2} \mathrm{~h}^{-1}\right)$, normalized $1012^{\circ} \mathrm{C}$

\begin{tabular}{lcccc|}
\hline Treatment & Tank & $\begin{array}{c}\text { Apr. 25- } \\
\text { May 17 }\end{array}$ & $\begin{array}{c}\text { Treatment } \\
\bar{x} \pm x\end{array}$ & C.V \\
\hline Control. & 1 & 36 & & \\
normal & 5 & 26 & $39 \pm 14$ & $36 \%$ \\
mixing & 4 & 54 & & \\
\hline $\begin{array}{l}\text { Continuous } \\
\text { mixing }\end{array}$ & 6 & 39 & $32 \pm 11$ & $33 \%$ \\
\hline No mixing & 3 & 24 & & \\
See legend to Table 1 & & & \\
\hline
\end{tabular}

Tank 3, i. e. lower than in any of the other treatments and consistent with the productivity results (Tables 1 and 2). If the higher values were accepted, Tank 3 would be heterotrophic since its respiration would have been greater than its production. This pattern seems unlikely. Nighttime respiration was higher in the continuously mixed tanks than in the control or oilrecovery tanks. Benthic respiration measured at the end of the experiment was not very different in the three mixing treatments (Table 3 ). The rate measured in the unmixed tank was within the range measured in the other treatments.

\section{Chlorophyll and Nutrients}

Chlorophyll concentrations tended to be higher in tanks continuously mixed than in the unmixed tank, in agreement with the differences in productivity (Table 4. Fig. 2). When the brine bottle broke in Tank 8 , the chlorophyll level was high. When the tank was refilled, the concentration was very low. However, it rose 


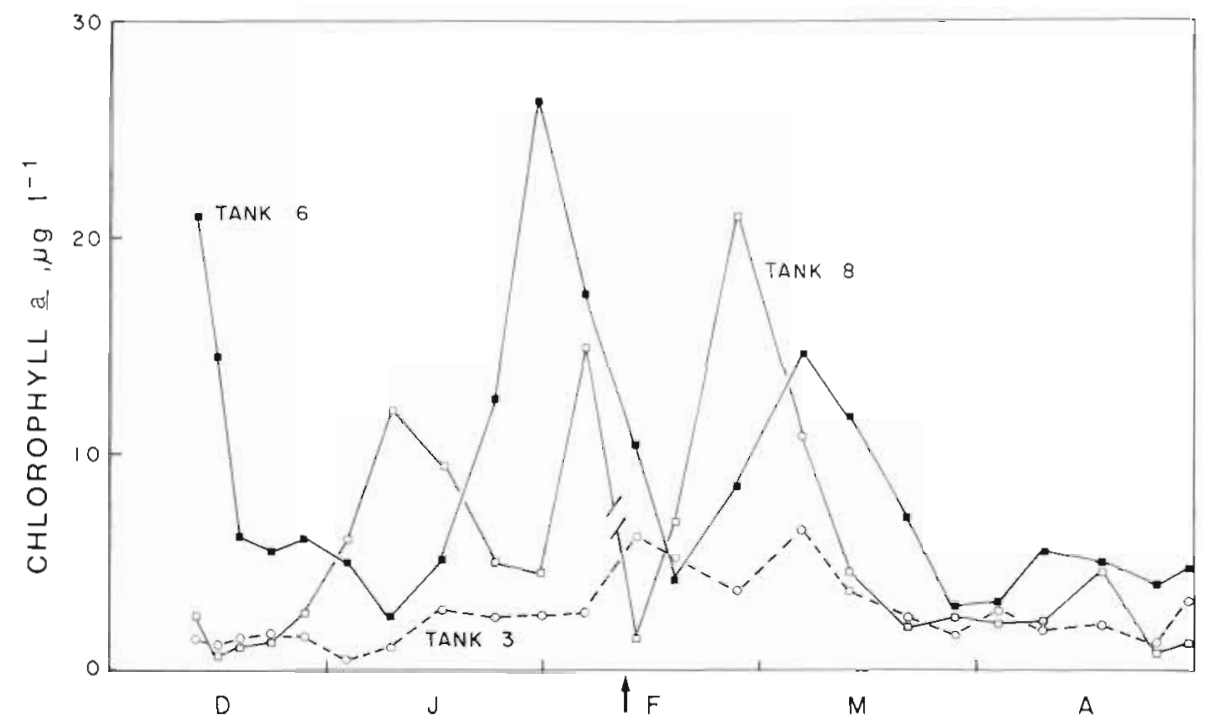

Fig. 2. Chlorophyll a concentrations in continuously mixed tanks ( 6 and 8 ) and in the unmixed tank (3) from December through April. Arrow indicates time when heat exchanger bottle broke in Tank 8 (see text)

rapidly (Fig. 2). The chloraphyll concentration was lower in the unmixed tank (3) than in any of the others (Table 4).

Stratifications occurred in Tank 3 between wall: cleanings (Fig. 3). Chlorophyll concentrations increased and nutrient concentration decreased in surface waters. A week or so after blooms of phytoplankton in surface waters, chlorophyll concentrations in bottom waters increased. Benthic fluxes of nutrients increased their concentrations in the bottom waters. Storms with rainfall can be correlated with increases of nitrate plus nitrite in surface waters. Nitrate plus nitrite increased in bottom waters following the buildup of ammonia in bottom waters.

Through January, nutrient concentrations were highest in Tank 3 (Fig. 4). The two continuously mixed tanks had low and almost identical nutrient concentrations during most of the experiment. Ammonia and silicate concentrations increased at the end of December and the beginning of January in Tank 6 , coincident with the decline of a December phytoplankton bloom in that tank (Figs 2 and 3). The silicate concentration remained high throughout the experiment in Tank 3, but ammonia and phosphate decreased to levels similar to the two continuously mixed tanks. These observations were consistent with phytoplankton cell counts which indicated that the continuously mixed tanks were dominated by a mixture of diatoms and flagellates, while the unmixed tank was dominated by flagellates (Table 5).

Table 4. Mean chlorophyll a concentrations ( $\left.\mu \mathrm{g}^{-1}\right)$ during mixing experiment

\begin{tabular}{|c|c|c|c|c|c|c|c|c|c|}
\hline Treatment & Tank & December & January & February & March & Aprnl & $\bar{X}$ & $\begin{array}{l}\text { Treatment } \\
\text { mean } \pm s\end{array}$ & C.V. \\
\hline $\begin{array}{l}\text { Control, } \\
\text { normal mixing }\end{array}$ & $\begin{array}{l}1 \\
5 \\
4\end{array}$ & $\begin{array}{l}1 \\
3 \\
2\end{array}$ & $\begin{array}{r}11 \\
17 \\
5\end{array}$ & $\begin{array}{l}6 \\
6 \\
8\end{array}$ & $\begin{array}{l}8 \\
5 \\
7\end{array}$ & $\begin{array}{l}5 \\
4 \\
5\end{array}$ & $\begin{array}{l}6 \\
7 \\
5\end{array}$ & $6 \pm 1$ & $17 \%$ \\
\hline $\begin{array}{l}\text { Continuous } \\
\text { mixing }\end{array}$ & $\begin{array}{l}6 \\
8\end{array}$ & $\begin{array}{r}11 \\
2\end{array}$ & $\begin{array}{r}10 \\
7\end{array}$ & $\begin{array}{l}12 \\
13\end{array}$ & $\begin{array}{l}9 \\
5\end{array}$ & $\begin{array}{l}5 \\
2\end{array}$ & $\begin{array}{l}9 \\
6\end{array}$ & $8 \pm 2$ & $19 \%$ \\
\hline No mixing & 3 & 2 & 2 & 4 & 2 & 3 & 3 & & \\
\hline $\begin{array}{l}\text { Oil recovery } \\
\text { normal mixing }\end{array}$ & $\begin{array}{l}2 \\
7 \\
9\end{array}$ & $\begin{array}{l}2 \\
7 \\
3\end{array}$ & $\begin{array}{r}11 \\
9 \\
9\end{array}$ & $\begin{array}{l}6 \\
8 \\
8\end{array}$ & $\begin{array}{l}8 \\
3 \\
6\end{array}$ & $\begin{array}{l}3 \\
5 \\
3\end{array}$ & $\begin{array}{l}6 \\
6 \\
6\end{array}$ & $6 \pm 0$ & $0 \%$ \\
\hline Bay & & 2 & 2 & 2 & 8 & 3 & 3 & 3 & \\
\hline
\end{tabular}




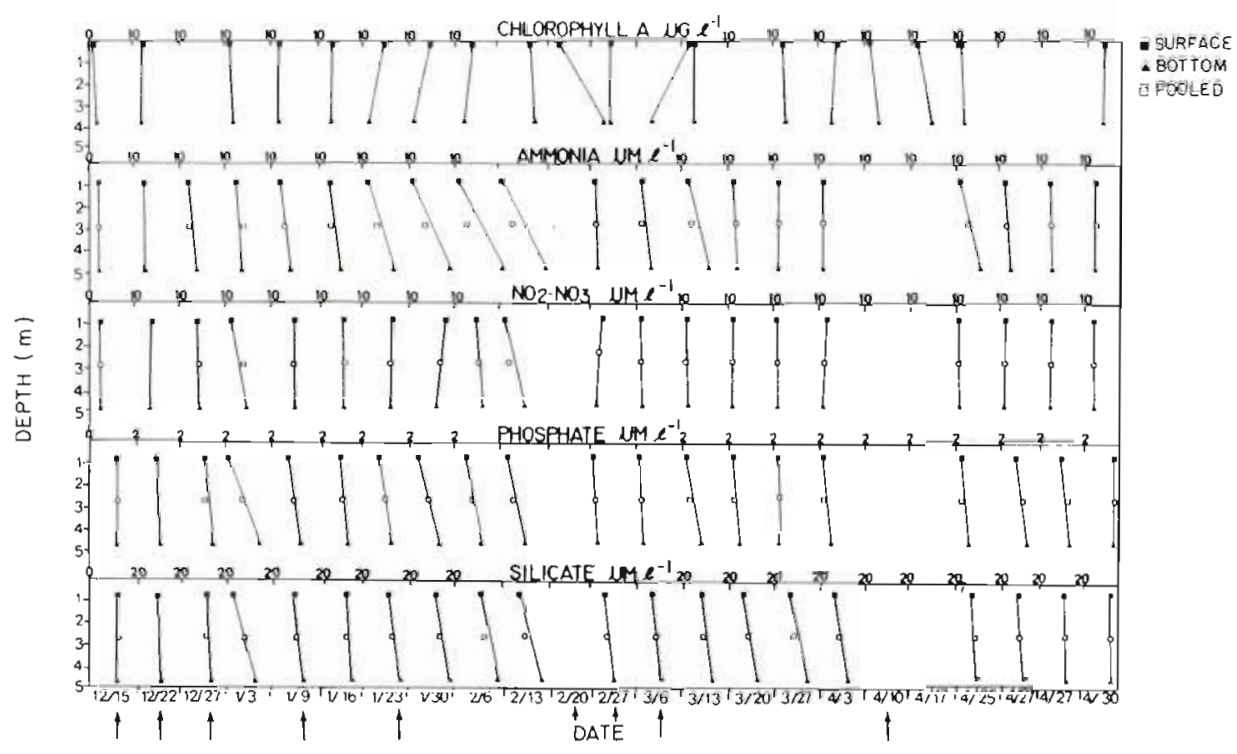

Fig. 3. Profiles of chlorophyll a and nutrient concentrations for unmixed tank (3). Open squares in nutrient profiles indicate the concentration of a pooled sample. Arrows: time of tank mixing caused by wall cleaning

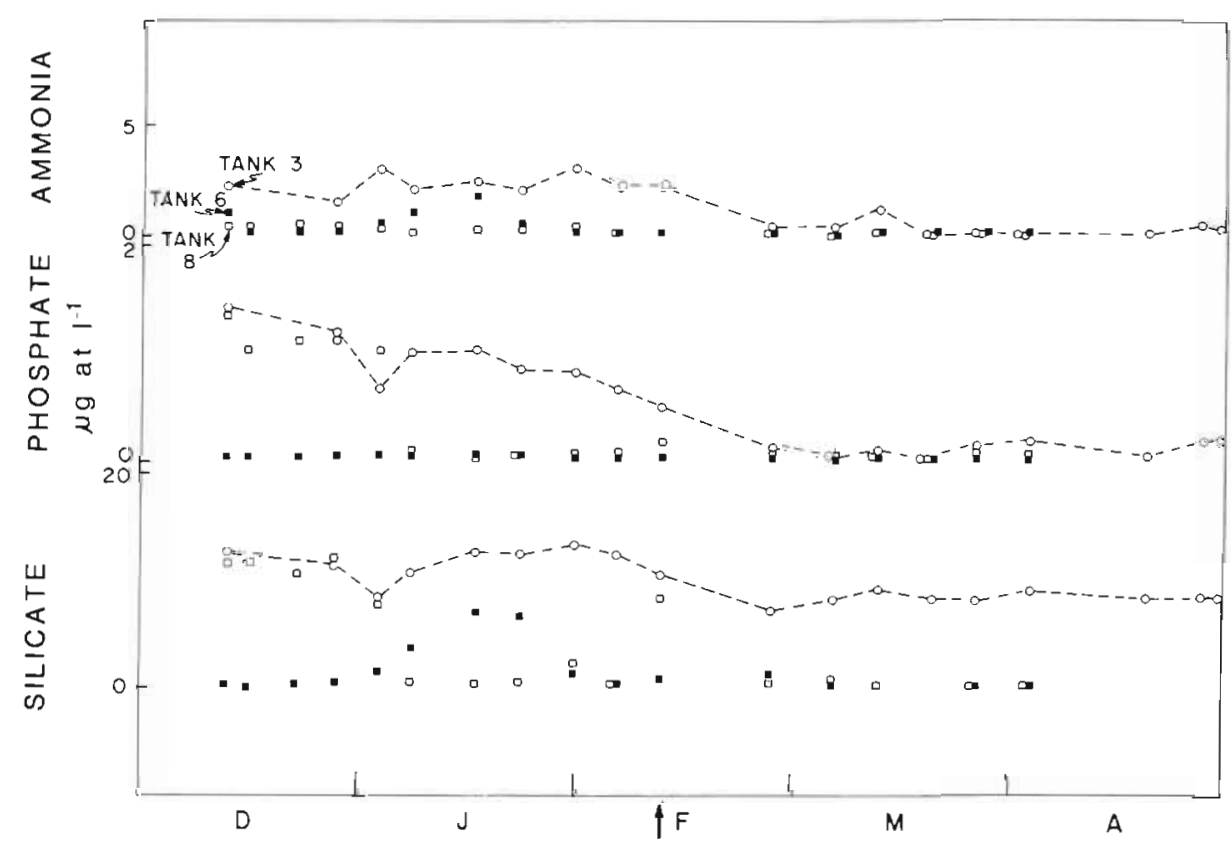

Fig. 4. Nutrient concentrations in continuously mixed tanks (6 and 8) and in unmixed tank (3) from December through April. Dashed line joins concentrations for pooled samples from Tank 3. Arrow: time when heat exchanger bottle broke in Tank 8

Table 5. Phytoplankton cell counts (No $\mathrm{ml}^{-1}$ ) during mixing experiment. n. s.: no sample

\begin{tabular}{|c|c|c|c|c|c|c|}
\hline \multirow{2}{*}{$\begin{array}{l}\text { Treatment } \\
\text { Tank: }\end{array}$} & & \multirow{2}{*}{$\begin{array}{c}\text { Control } \\
1\end{array}$} & \multirow{2}{*}{$\begin{array}{l}\text { Unmixed } \\
3\end{array}$} & \multicolumn{2}{|c|}{ Continuously mixed } & \multirow{2}{*}{$\begin{array}{c}\text { Oil recovery } \\
2\end{array}$} \\
\hline & & & & 6 & 8 & \\
\hline Date & Group & & & No $\mathrm{ml}^{-1}$ & & \\
\hline \multirow[t]{2}{*}{$4 /$ III/79 } & Total diatoms & 2800 & 0 & 1200 & n.s. & 2100 \\
\hline & Total $\mu \mathrm{m}$-flagellates & 1700 & 2200 & 2000 & n.s. & 2800 \\
\hline \multirow[t]{2}{*}{$4 / X / 79$} & Total diatoms & n.s. & 100 & 3400 & 300 & n.s. \\
\hline & Total $\mu \mathrm{m}$-flagellates & n.s. & 6100 & 2400 & 1100 & n.s. \\
\hline
\end{tabular}


Table 6. Benthic ammonia flux ( $\mu \mathrm{g}$ at $\left.\mathrm{m}^{-2} \mathrm{~h}^{-1}\right)$, normalized to $12^{\circ} \mathrm{C}$

\begin{tabular}{|ccccc|}
\hline Treatment & Tank & $\begin{array}{c}\text { Apr. 26- } \\
\text { May 17 }\end{array}$ & $\begin{array}{c}\text { Treatments } \\
\bar{X} \pm S\end{array}$ & C.V \\
\hline Control & 1 & 119 & $76 \pm 43$ & $56 \%$ \\
norm. mixing & 5 & 34 & & \\
& 4 & 75 & & $3 \%$ \\
\hline Continuous & 6 & 74 & $73 \pm 2$ & $3 \%$ \\
mixing & 8 & 71 & 126 & \\
\hline No mixing & 3 & 126 & & \\
- See legend to Table 1 & & & \\
\hline
\end{tabular}

The decline in nutrients in the unmixed tank during February suggested that contrary to indications from productivity rates and chlorophyll concentrations the phytoplankters were growing rapidly in this treatment. Benthic ammonia flux, measured at the end of the experiment, was highest in Tank 3 ; this also suggests a higher particulate flux of organic material to the bottom (Table 6).

\section{Species Composition}

Throughout the experimental period $\mu \mathrm{m}$-flagellates dominated in the unmixed microcosm (3) although normally occurring diatoms were also present (Table 7). A mixture of flagellates and diatoms dominated in the continuously mixed microcosms (6 and 8). In Tank 6 Dinobryon sp. and Cylindrotheca fusiformis were benthic and probably originated from the walls of the tank. Comparisons of the number of phytoplankton species in each treatment cannot be made since the number of counts was different and because $\mu \mathrm{m}$-flagellates were not identified to species. However, more zooplankton species occurred in the unmixed treatment than in the continuously mixed treatment, although Acartia clausi dominated in both treatments (Table 7). In Tank 3, 10 species of copepods were present; in Tank 6, 6 species and in Tank 8, 7 species.

\section{Zooplankton}

Copepods adults and nauplii, zooplankton biomass, and rotifers were most abundant in the unmixed tank (Figs 5 and 6, Table 8). There were more adult copepods during December and January in Tank 3 than in the control and continuously mixed tanks. Copepod numbers in Tank 3 were much higher in February, March, and April (Figs 5 and 6). At the end of the experimen 7700 adult copepods $\mathrm{m}^{-3}$ were estimated in Tank 3; less than a third of this number were in the control tanks and even fewer in the continuously

Table 7. Species composition

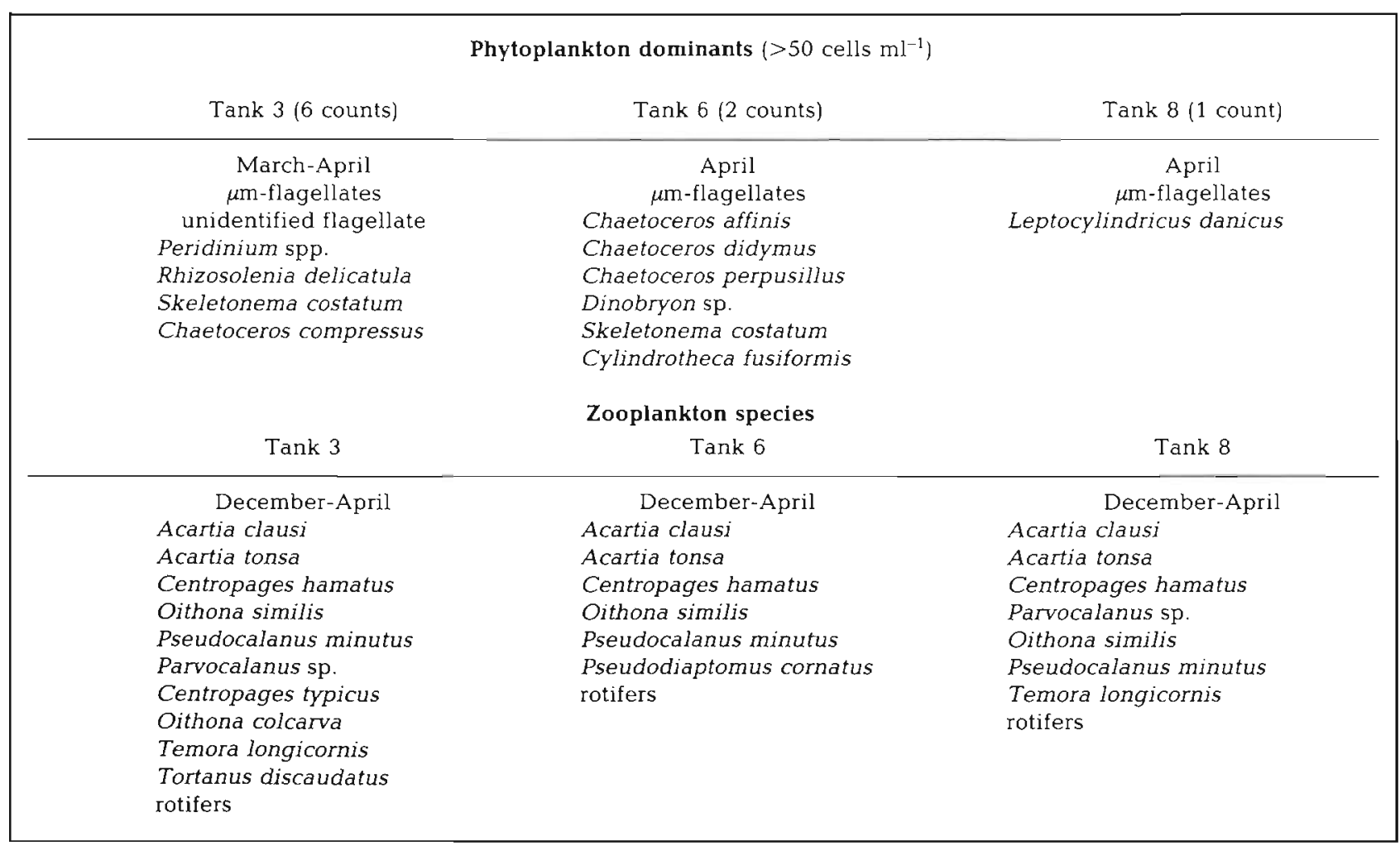


Table 8. Mean zooplankton biomass during 5 month experiment and rotifer numbers during last 2 months of experiment Zooplankton and rotifer means based on weekly samples

\begin{tabular}{|c|c|c|c|c|c|}
\hline \multirow[b]{2}{*}{ Treatment } & \multicolumn{3}{|c|}{ Zooplankton biosmass (mg dry wt $\mathrm{m}^{-2}$ ) } & \multicolumn{2}{|c|}{ Rotifers (No $\mathrm{m}^{-3}$ ) } \\
\hline & Tank & $\bar{X} \pm S$ & Treament $\bar{X}$ & $\bar{X} \pm S$ & Treatment $\bar{X}$ \\
\hline \multirow{3}{*}{ Control, normal mixing } & 1 & $15 \pm 15$ & \multirow{3}{*}{15} & $300 \pm 300$ & \multirow{3}{*}{2400} \\
\hline & 5 & $15 \pm 11$ & & $4400 \pm 5000$ & \\
\hline & 4 & $15 \pm 15$ & & $2500 \pm 5200$ & \\
\hline \multirow[t]{2}{*}{ Continuous mixing } & 6 & $11 \pm 15$ & \multirow{2}{*}{10} & $500 \pm 1000$ & \multirow{2}{*}{300} \\
\hline & 8 & $9 \pm 6$ & & $100 \pm 100$ & \\
\hline No mixing & 3 & $35 \pm 29$ & 35 & $28000 \pm 26100$ & 28000 \\
\hline \multirow[t]{3}{*}{ Oil recovery } & 2 & $17 \pm 19$ & \multirow{3}{*}{19} & \multirow{3}{*}{0} & \multirow{3}{*}{0} \\
\hline & 7 & $16 \pm 15$ & & & \\
\hline & 9 & $23 \pm 9$ & & & \\
\hline Bay & & $26 \pm 18$ & 26 & 0 & 0 \\
\hline
\end{tabular}

mixed tanks. Acartia clausi nauplii which dominated in numbers were also much lower in the continuously mixed tanks (6 and 8) than in the unmixed tank (3). One-point peaks of nauplii were coincident with onepoint peaks of adults, except for the last 3 weeks of the

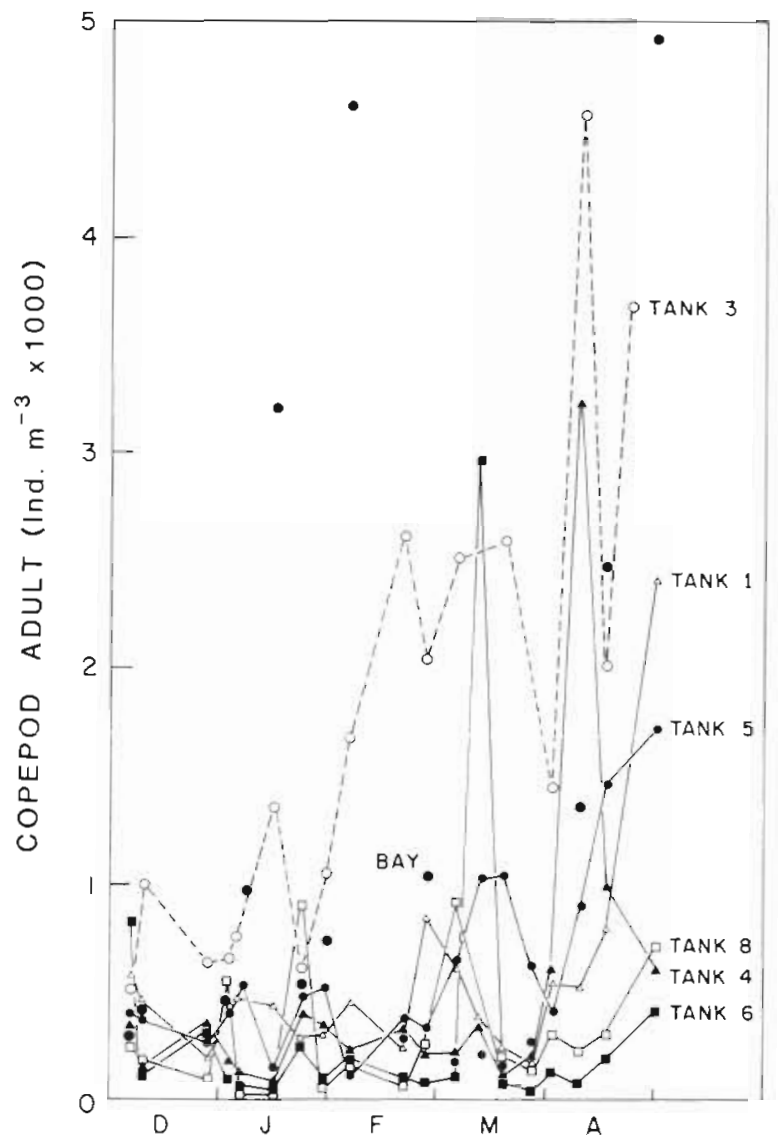

Fig. 5. Numbers of adult copepods during mixing experiment Tank 3 unmixed; Tanks 6 and 8 continuously mixed; Tanks 1. 4 , and 5 mixed on a schedule of $2 \mathrm{~h}$ on, $4 \mathrm{~h}$ off experiment in the continuously mixed tanks. A more normal pattern of lagged peaks occurred in unmixed Tank 3 .

The pattern of a low biomass of rapidly growing phytoplankton grazed by a large population of zoo-

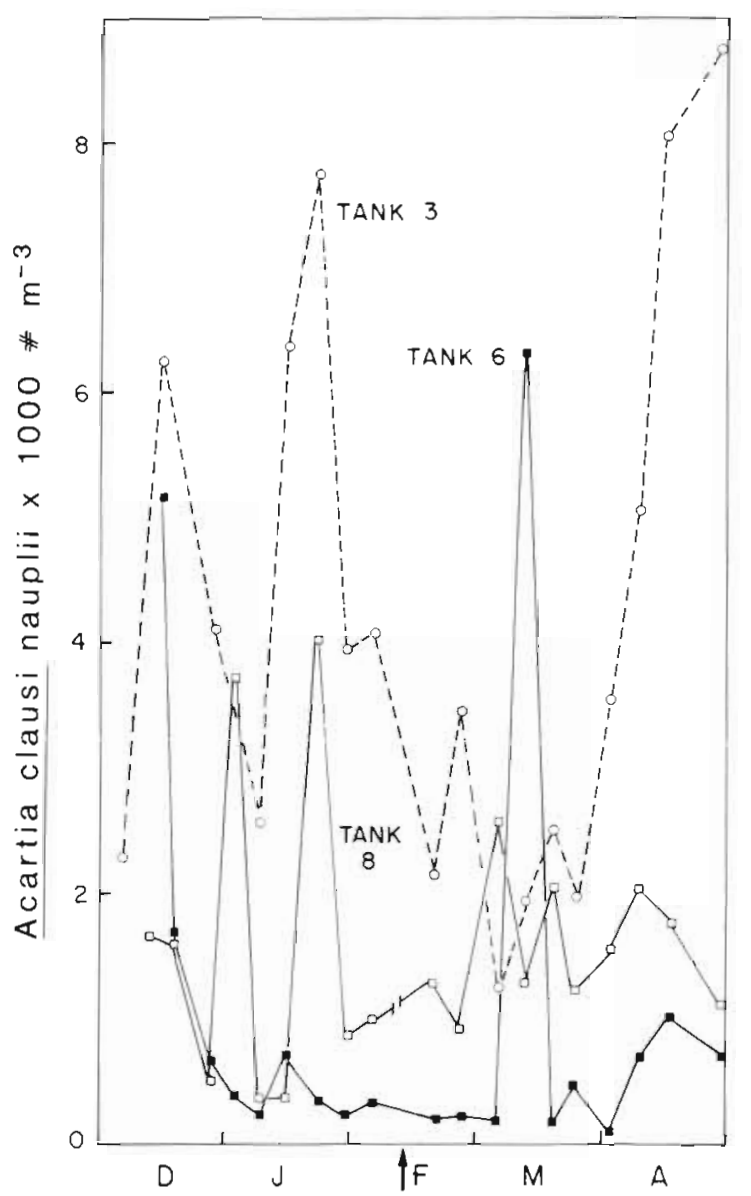

Fig. 6. Number of zooplankton nauplii in tanks during mixing experiment. Tank 3 unmixed; Tank 6 continuously mixed 


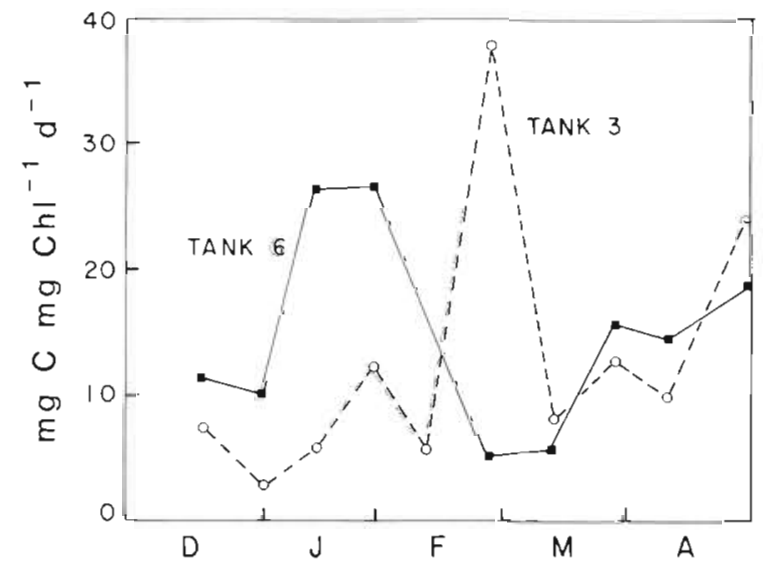

Fig. $7 .{ }^{14} \mathrm{C}$ production normalized to chlorophyll biomass in unmixed tank (3) and continuously mixed tanks ( 6 and 8) from December through April

plankton emerges for the unmixed tank. Zooplankton fecal pellet deposition may be the cause of the higher benthic ammonia flux in this treatment (Table 6). ${ }^{14}$ Carbon phytoplankton productivity when normalized to chlorophyll indicated that the phytoplankters were growing at equal rates in both Tank 3 during the period of highest zooplankton abundance and Tank 6 (Fig. 7). Thus while the biomass of phytoplankton was higher in the continuously mixed tanks than in the unmixed tanks, phytoplankton were growing at similar rates in both treatments. From the zooplankton biomass from Tank 3 of $35 \pm 29 \mathrm{mg}$ dry wt $\mathrm{m}^{-2}$ and a maximum excretion rate of $2 \mu \mathrm{g}$-at $\mathrm{NH}_{3} \mathrm{mg}^{-1}$ dry-wt. $\mathrm{d}^{-1}$ from December to April (Vargo, 1979), an excretion rate of $12-128 \mu \mathrm{g}$-at $\mathrm{m}^{-2} \mathrm{~d}^{-1}(\overline{\times} 70)$ can be calculated. These daily values are small and roughly equivalent to the hourly rates of benthic flux (Table 6). Thus phytoplankton production in Tank 3 was probably not as dependent on zooplankton excretion of nitrogen as it was on benthic ammonia release.

\section{DISCUSSION}

\section{Treatment Efiects}

Clearly different ecological events occurred in microcosms with different mixing schedules. The greater primary productivity of continuously mixed microcosms was a function of higher biomass of chlorophyll rather than faster phytoplankton growth rates. As a consequence, lower nutrient concentrations resulted in the continuously mixed microcosms than in the unmixed microcosms. The unmixed water column showed stratification patterns for nutrients and chlorophyll. Phytoplankton production in surface water and nutrient flux from the benthos resulted in low nutrient concentrations in surface waters and high concentrations in bottom water. During blooms chlorophyll concentrations were elevated in surface waters; after blooms they were elevated in bottom waters. Species composition was correlated with the mixing treatments with flagellates and rotifers abundant in the unmixed microcosm.

\section{Zooplankton}

In earlier attempts to sort out the effects of mixing on phytoplankton and zooplankton in small microcosms (150 l), we sometimes had conflicting results (Perez et al., 1977; Nixon et al., 1979). The simplified results for these 15-30 d experiments are summarized in Table 9. Generally, increased turbulence had little or no effect during the coldest months. With warmer temperatures, increased turbulence resulted in increased phytoplankton biomass probably as a consequence of reduced zooplankton biomass and therefore grazing pressure. During the present long-term experiment in large microcosms we have observed decreased zooplankton and increased phytoplankton under continuous mixing during cold-water periods as well as during warm-water periods, although the effects were clearly larger during warm-water periods. In both experiments it seems clear that decreased zooplankton allowed phytoplankton biomass to increase. In the present experiment, phytoplankton when normalized to chlorophyll grew equally well in continuously mixed and unmixed tanks although the species composition was different (Fig. 7).

During earlier experiments we had thought that the method of mixing might be disrupting zooplankton feeding or reproductive activity. The small microcosms were mixed with plastic mesh $(1.2 \times 1.2 \mathrm{~cm})$ paddles which reversed direction every $30 \mathrm{~s}$ at $32 \mathrm{rpm}$ (Nixon et al., 1979). In the present experiment the decreased zooplankton in continuously mixed tanks does not appear to be a mechanically caused artifact. The mixing regime in the large microcosms was much more gentle and there was no mechanical device constantly moving through a large percentage of the water column. In a CEPEX experiment employing gentle stirring caused by bubbling air once a week for 4-5 min and daily for 30-65 s, larger diatoms were maintained in the water column but no differences in the standing crop of phytoplankton or herbivorous zooplankton were observed (Eppley et al., 1978). However, in another CEPEX experiment apparently more carbon was utilized by herbivores in an unmixed enclosure than in a mixed enclosure (Sonntag and Parsons, 1979).

One possibility that seems worth testing has to do with the distribution of zooplankton in the water column. It is likely that in the natural system with its 
Table 9. Effects of increased mixing on phytoplankton and zooplankton in $150 \mathrm{l}$ marine microcosmos. (After Perez et al., 1977 and Nixon et al., 1979)

\begin{tabular}{|c|c|c|c|c|}
\hline Month & Temperature & Comparison of mixing conditions & Phytoplankton & Zooplankton \\
\hline April & $8^{\circ}-12^{\circ} \mathrm{C}$ & $\begin{array}{l}\text { No paddle vs } 1 / 2 \text { size paddle } \\
\text { to } 1 \text { paddle, with zooplankton }\end{array}$ & Dramatic increase & Decrease \\
\hline May & & Same experiment, same results & & \\
\hline December & $1^{\circ}-6^{\circ} \mathrm{C}$ & $\begin{array}{l}\text { No paddle vs } 1 \text { paddle, } \\
\text { no zooplankton } \\
\text { with zooplankton }\end{array}$ & $\begin{array}{l}\text { No response } \\
\text { Slight increase }\end{array}$ & $\stackrel{-}{\text { Slight increase }}$ \\
\hline February & $0^{\circ}-3^{\circ} \mathrm{C}$ & $\begin{array}{l}\text { No paddle vs } 1 \text { paddle, } \\
\text { no zooplankton } \\
\text { with zooplankton }\end{array}$ & $\begin{array}{l}\text { No response } \\
\text { No response }\end{array}$ & $\stackrel{-}{\text { No response }}$ \\
\hline July & $19^{\circ}-20^{\circ} \mathrm{C}$ & $\begin{array}{l}\text { No paddle vs } 1 \text { paddle, } \\
\text { no zooplankton } \\
\text { with zooplankton }\end{array}$ & $\begin{array}{l}\text { Increase } \\
\text { Increase }\end{array}$ & Decrease \\
\hline August & $19^{\circ}-21^{\circ} \mathrm{C}$ & $\begin{array}{l}\text { No paddle vs } 1 \text { paddle, } \\
\text { no zooplankton } \\
\text { with zooplankton }\end{array}$ & $\begin{array}{l}\text { Dramatic increase } \\
\text { Increase }\end{array}$ & Decrease \\
\hline
\end{tabular}

strong horizontal advections, the different age classes and zooplankton species may be segregated at different depths. Often the juveniles and sometimes also the adult copepods aggregated in the surface waters of the MERL microcosms during nonmixing periods (Raridon, 1979). During mixing, strong vertical advection would break down such segregation between adult and juvenile copepods. This integration might result in increased cannibalism. Mixing to homogeneity may also have caused increased cannibalism in the small microcosms. This possibility is consistent with the observation of higher zooplankton in the bay than in the tanks, even though the turbulence was higher in the bay than in the tanks.

An alternative explanation for the low zooplankton values is that the zooplankton in the continuously mixed tanks were eating more resuspended material lower in nutrient content and thus growing and reproducing more slowly despite the high chlorophyll levels. Paffenhöfer (1972) has found reduced growth and increased mortality for Calanus helgolandicus exposed to concentrations of $0.6-6.0 \mathrm{mg} \mathrm{l}^{-1}$ of nontoxic 'red mud' and Sherk et al. (1975) established that Acartia tonsa exhibited drastic reductions in maximum ingestion in all concentrations of nontoxic particle types tested. A. tonsa were more sensitive than copepod species accustomed to higher levels of suspended load. However, the evidence was weak for this explanation as the suspended loads were not different (2-4 $\mathrm{mg} \mathrm{l}^{-1}$ in the three mixing treatments, and they were generally lower than in the bay $\left(5 \mathrm{mg} \mathrm{^{-1 }}\right.$ ).

Zooplankton abundance and biomass were less in the continuously mixed tanks than in all other treat- ments. All of our measures of turbulence suggest that mixing energy is greater in Narragansett Bay than in the microcosms (Nixon et al., 1980). Nevertheless, zooplankters were more abundant in the bay than in any of the tanks, except in the unmixed tank. The fewer zooplankters in the continuously mixed tank do not appear to have been due to straightforward effect of turbulence. The higher phytoplankton biomass may, however, be inferred as resulting from the reduced grazing pressure due to the fewer zooplankters present.

Acknowledgements. As with all our microcosm experiments many people participated in this study. Total system metabolism was measured by Aimee Keller and Betty Buckley. Phytoplankton and nutrients were determined by Gabriel Vargo, Melissa Hutchins, and Glenn Almquist. Benthic respiration and nutrient regeneration were measured by John Kelly. Zooplankton numbers and biomass were recorded by Maureen McConnell. Patrick Gearing read and helpfully critized the manuscript. This work was supported by EPA grant R.806072020

\section{LITERATURE CITED}

Degobbis, D. (1973). On the storage of seawater samples for ammonia determination. Limnol. Oceanogr 18: 146-150

Elmgren, R., Grassle, J.F., Grassle, J.P., Heinle, D.R., Langlois, G., Vargo, S.L., Vargo, G.A. (1980). Trophic interactions in experimental marine ecosystems perturbed by oil. In: Giesy, J.P. (ed.) Microcosms in Ecological Research. DOE Symposium Series, Augusta, GA, Nov. 8-10, 1978. CONF 781101, NTIS, pp. 779-800

Eppley, R.W., Koeller, P., Wallace, G.T.Jr. (1978). Stirring influences the phytoplankton species composition within enclosed columns of coastal seawater. J. exp. mar. Biol. Ecol. 32: 11-31 
Friederick, G.O., Whitledge, T (1972). Autoanalyzer procedures for nutrients. In: Parlou, S.D. (ed.) Chemostat methodology and chemical analyses. Dept. Oceanography, University of Washington, Seattle (Spec. Rep. 52) pp. $38-60$

Holm-Hansen, O., Lorenzen, C.T., Holmes, R.W., Strickland, J.D.H. (1965). Fluorometric determination of chlorophyll. J. Cons. perm. int. Explor. Mer 31: 3-15

Nixon, S.W., Oviatt, C.A., Buckley, B.A. (1979). Turbulent mixing in marine microcosms - some relative measures and ecological consequences. In: Jacoff, F.D. (ed.) Advances in marine environmental research. EPA-600/9-79035, U.S.E.P.A., Narragansett, R.I., pp. 382-409

Nixon, S.W., Alonso, D., Pilson, M.E.Q., Buckley, B.A. (1980). Turbulent mixing in aquatic microcosms. In: Giesy, J.P. (ed.) Microcosms in ecological research. DOE Symposium Series, Augusta, GA, Nov. 8-11 , 1978. CONF 781101, NTIS, pp. 779-800

Odum, H.T., Hoskin, C.M. (1958). Comparative studies on the metabolism of marine water. Publs Inst. mar. Sci. Univ. Tex. 5: $16-46$

Oviatt, C.A., Perez, K.T., Nixon, S.W. (1977). Multivariate analysis of experimental marine ecosystems. Helgoländer wiss. Meeresunters. 30: 30-46

Oviatt, C.A., Buckley, B., Nixon, S.W. (1981). Annual phytoplankton metabolism in Narragansett Bay calculated from survey field measurements and microcosm observations. Estuaries (in press)

Oviatt, C.A., Hunt, C.D., Vargo, G.A., Kopchynski, K.W., Storm simulation in marine microcosms (submitted)

Paffenhöfer, G.A. (1972). The effects of suspended 'red' mud on mortality, body weight, and growth of marine planktonic copepod, Calanus helgolandicus. Water, Air \& Soil Pollut. 1: 318-321

Parsons, T.R., Harrison, P.J., Waters, R. (1978). An experimental simulation of changes in diatom and flagellate blooms. J. exp. mar. Biol. Ecol. 32: 285-294
Perez, K.T., Morrison, G.M., Lackie, N.F., Oviatt, C.A., Nixon, S.W., Buckley, B.A., Heltsche, J.F. (1977). The importance of physical and biotic scaling to the experimental simulation of a coastal matine ecosystem. Helgoländer wiss. Meeresunters. 30: 144-162

Pilson, M.E.Q., Oviatt, C.A., Vargo, G.A., Vargo, S.L. (1979). Replicability of MERL microcosms; initial observations. In: Jacoff, F.S. (ed.) Advances in marine environmental research. EPA-600/9-79-035, U.S.E.P.A., Narragansett, R.I., pp. 359-381.

Pilson, M.E.Q., Oviatt, C.A., Nixon, S.W (1980). Annual nutrient cycles in a marine microcosm. In: Giesy, J.P. (ed.) Microcosms in ecological research. DOE Symposium Series, Augusta, GA, Nov. 8-10, 1978. CONF 781101, NTIS, pp. 753-778

Raridon, A. (1979). NSF summer student studying vertical distribution of zooplankton in the MERL tanks. Marine Ecosystems Research Laboratory Newsletter No. 26, August 1979

Sherk, J.A., O'Connor, J.M., Neumann, D.A. (1975). Effects of suspended and deposited sediments on estuarine environments. In: Cronin, L.E. (ed.) Estuarine research, Vol. II. Academic Press, New York, pp. 541-558

Solorzano, L. (1969). Determination of ammonia in natural waters by phenol hypochlorite method. Limnol. Oceanogr. 14: 799-801

Sonntag, N.C., Parsons, T.R. (1979). Mixing an enclosed, $1300 \mathrm{~m}^{3}$ water column: effects on the planktonic food web. J. Plankton Res. 1: 85-102

Strickland, J.D.H., Parsons, E.R. (1972). A practical handbook of seawater analysis. Bull. Fish. Res. Bd Can. 169: 1-310

Thomas, W.H., Seibert, D.L.R. (1977). Effects of copper on the dominance and the diversity of algae: controlled ecosystem pollution experiment. Bull. mar. Sci. 27: 23-33

Vargo, G. (1979). The contribution of ammonia excreted by zooplankton to phytoplankton production in Narragansett Bay. J. Plankton Res. 1: 75-83 